\title{
Discussion on the Interest Appeal of the Sino-Russian Economic and Trade Cooperation
}

\author{
Yanling Zhou \\ School of Economics \\ Heihe University \\ Heihe, China 164300
}

\begin{abstract}
In 2017, the 19th National People's Congress of the Communist Party of China clearly specified China's development direction in the future, formulated the basic strategy and blueprint for China's future development, and proposed that in the new era China's diplomacy should unswervingly carry out friendly cooperation with other countries on the basis of the Five Principles of Peaceful Coexistence. In March 2018, Putin was re-elected as president of Russia; and since then, Russia entered a new stage of development. In this context, while attaching importance to the quality of cooperation, Sino-Russian economic and trade cooperation will pay attention to the respective interests and common interests of both sides, and will be carried out in a deeper level.
\end{abstract}

Keywords-Sino-Russian; economic and trade cooperation; interests

\section{INTRODUCTION}

In 2017, the 19th National People's Congress of the Communist Party of China clearly specified China's development direction in the future, formulated the basic strategy and blueprint for China's future development, and proposed that in the new era China's diplomacy should unswervingly carry out friendly cooperation with other countries on the basis of the Five Principles of Peaceful Coexistence, promote the construction of new international relations, and boost the building of a community with shared future for mankind. In March 2018, Putin was re-elected as president of Russia; and since then, Russia entered a new stage of development. In this context, while attaching importance to the quality of cooperation, Sino-Russian economic and trade cooperation will be carried out in a deeper level.

\section{INTEREST APPEAL OF CHINA}

\section{A. The Cooperation Should Be Helpful for China to Solve the Problem of Surplus Capacity in Manufacturing Industry}

According to data released by the United Nations Industrial Development Organization, China has become the largest manufacturing country in the world. The added value of manufacturing industry accounts for about one fifth of the world. Export is a key factor affecting economic growth and a key factor driving China's economic development. However in 2008, impacted by the financial crisis, manufacturing exports fell sharply. In 2011, in order to promote maintaining a basic balance between import and export trades, the government adopted the "expanding import strategy"; imported finished products occupied partial domestic market share of some domestic manufacturing industries, resulting in very limited utilization of production capacity. In 2012, the utilization rate of manufacturing capacity was only $70 \%$ of that in 2007 . In 2018 , the rate was $76.9 \%$, and rose again by $0.6 \%$ from that of the same period of the previous year. Therefore, expanding exports is the most effective way to solve the problem of surplus capacity in China's manufacturing industry. The key point of SinoRussian economic cooperation is to establish an unimpeded trade channel. Taking advantage of the trade channel, China can expand the export of finished products, and promote Chinese manufacturing industry to expand investment overseas while digesting domestic surplus capacity.

\section{B. The Cooperation Should Be Helpful for China to Maintain the Economy in Continuous High-speed Growth}

According to statistics from national departments, in the first three quarters of 2018, China's total value of import and export trade of goods was 22.28 trillion Yuan, increased by $9.9 \%$ of that in the same period last year. It can be seen that since 2018 China's foreign trade has developed well and at the same time the development quality has been improved. The overall situation is under control even if there are some interference factors in the international range; especially the Sino-US trade friction has seriously hindered China's foreign trade development. In recent years, under the influence of changes in the international situation, China's foreign trade and investment have decreased significantly. However in order to stabilize the domestic economic growth situation, it is still necessary to take advantage of the influence of foreign trade and investment to increase the scale of capital investment, and make full use of the advantages of advanced technology to increase the input of related industries and promote steady economic growth. The further deepening of Sino-Russian cooperation has laid a good foundation for the cooperation between the two countries in large-scale projects and will promote the common development of the two countries. 


\section{The Cooperation Should Be Helpful for China to Open up the Transport Channel for New Energy Import}

After 40 years of reform and opening up, China has been in a stage of rapid economic development, but its dependence on imported energy is increasing day by day. At the end of the last century, China changed from a petroleum exporter to a net petroleum importer. In 2017, China's dependence on foreign petroleum imports reached nearly $70 \%$. Since 2009, the dependence has successively broken the oil safety warnings for many years. In 2013, the dependence on foreign import of natural gas reached $31.6 \%$, which means that nearly one third of China's natural gas came from foreign countries. In 2018, China became the world's largest natural gas importer, with the dependence on foreign import reaching $45.3 \%$. 90\% of China's imported oil came from the ocean. Among ocean transportation routes for conveying petroleum and natural gas, only a few countries took the Pacific route, and most other countries had to pass through the Straits of Malacca, so that the Straits of Malacca directly became a key point for China's petroleum and natural gas transportation. Currently, the Straits of Malacca is regarded as the Fortress on the sea by the United States although it is under jurisdiction of Indonesia, Malaysia and Singapore. The Strait of Malacca controls Japan's petroleum imports so that the United States, Japan and India are rush to control this channel. The relationship between the above six countries and China will interfere with the safe transportation of China's petroleum and natural gas. In order to solve this issue, China strengthens the cooperation with neighboring countries by construction of the "Belt \& Road" and is striving to build a new energy transport channel.

\section{INTEREST APPEAL OF RUSSIA}

In January 2010, Putin approved the "Social and Economic Development Strategy for the Far East and Baikal Regions before 2025". In March 2014, Russia put forward the "Trans-Eurasian Development Belt" with the purpose of developing Siberia and promoting the development of the Far East region. Through gradual advancement of the construction of the Eurasian railway, Eurasian Economic Union can dock with the "Belt \& Road" strategy and the "China-Mongolia-Russia Economic Corridor" proposed by China.

\section{A. The Cooperation Should Be Helpful for Russia to Go out of the Economic Sanction Dilemma and Open up New Development Fields}

According to the data of the International Monetary Fund, Russia's economic strength has declined significantly since the 1990s. Due to the Ukrainian incident in 2014, the United States and Europe imposed economic sanctions on Russia so that Russia, just recovered from the financial crisis, got into dilemma again. In 2017, Russia's economic strength fell to the twelfth place in the world. Due to the dramatic change in economic growth and the harsh situations such as inflation, rouble devaluation and the sharp decline in exports, Russia urgently needed to open up a new path of economic development. Thereby, the strategic cooperation between China and Russia will gradually boost the construction of energy and transportation infrastructures, which will drive Russia to get out of the predicament of sanction.

\section{B. The Cooperation Should Be Helpful for Russia to Take Its Advantage in Eurasia Region and Make Full Use of Its Transport Capacity}

Russia's geographical advantage makes Russia become a very critical transit transport country. The Far East region can take the location advantage of a long coastline and borderline, and thus has huge transit transport potential. In September 2009, China and Russia reached the "Outline of Cooperation Planning between the Northeastern region of China and the Far East and Eastern Siberia regions of the Russian Federation (2009-2018)"; in this Outline, the construction and transformation of Sino-Russian ports and border infrastructures, and the transport cooperation between China and Russia are placed in crucial position. On January 20, 2010, the Russian President approved the "Social and Economic Development Strategy for the Far East and Baikal Regions before 2025"; in this Strategy, the main objective of the second stage attached importance to transit passenger and freight traffic and the establishment of a core transport network. From this, it can be seen that Russia's Siberia and the Far East regions have focused their development on transportation. The Sino-Russian economic cooperation strategy will gradually play a leading role to enable Russia to make full use of the "Silk Road Economic Belt" transportation advantage, promote the construction progress of the transport network in Siberia and the Far East regions, and intensify efforts to improve transportation facilities to enhance passenger and cargo transportation capacity.

\section{COMMON INTEREST APPEALS OF CHINA AND RUSSIA}

The Sino-Russian regional economic cooperation strategy should jointly seek for common cooperation objectives while adhering to the principle of their respective cooperation principles, rely on their respectively rich resources to expand the scale of investment, as well as simplify the cooperation procedures, to lay a solid foundation for the establishment of a Sino-Russian free trade zone.

\section{A. The Cooperation Should Be Helpful to Expand the Field of Sino-Russian Economic and Trade Cooperation}

For a long time, China and Russia have selected laborintensive and resource-intensive models as the key cooperation objects in the economic and trade cooperation, relying on their respective advantages, while the proportion of services and technology trade is not high, and the scale of investment involved in the cooperation is limited; and the projects under cooperation are all energy-related projects. This case somewhat slows down the progress of economic and trade cooperation between the two countries and has less effect on promoting the economic development. To build China's "Silk Road Economic Belt" program, the first thing necessary to do is to solve the problem of transportation, namely to establish a smooth economic and trade cooperation corridor on land. Through this program, more practical infrastructures and projects (such as railways, 
highways, energy pipelines and industrial parks) will be constructed in countries along the route to solve problems such as poor transportation and serious infrastructure shortages so as to provide an unimpeded transportation in true sense for communication of goods between China and the western countries. China's neighboring countries are supportive in the construction of the "Silk Road Economic Belt". In February 2014, Russian president announced that Russia would join the construction of China's "Silk Road Economic Belt". In May 2015, the Sino-Russian joint statement proposed that the two sides should cooperate in large-scale investment projects, and jointly complete the construction of industrial parks and cross-border economic cooperation zones, especially attach importance to the connection between logistics, transportation infrastructures and multimodal transport fields. China and Russia should vigorously cooperate in the development of infrastructure projects, and constantly improve infrastructures to create a good development environment for both sides. Based on the cooperation strategy, Russia will make full use of China's resources both in capital and technology to create a good and rapid development condition for Russia.

\section{B. The Cooperation Should Be Helpful to Adjust and Upgrade the Two Countries' Industrial Structures}

At present, the two countries' modernization construction is in the key period of transformation. The strategic cooperation and docking between the two countries can create a huge space for the coexistence of their economic interests. China's reform and opening up has entered the 41st year. Over the years, China has undergone earth-shaking changes and constant economic growth which accumulates huge fund for China while constantly improving the technological level. At the same time, over years of reform, China's labor cost has increased year by year, while the quality of labor force has also increased substantially, providing a strong support for China's manufacturing transformation from labor-intensive type to capital-intensive and technology-intensive types. On the one hand, Russia's manufacturing is in desperate need of substantial funding and technological support. On the other hand, Russian economy needs to adjust its direction, reduce its dependence on energy production and exports, and actively avoid foreign risks. And in addition to capital and technology, Russia needs enough high-quality labor forces to develop Siberia and the Far East regions. Therefore, the Sino-Russian strategic docking will enable Chinese capital to be output to Russia more quickly, while transporting technology and labor forces to Russia and be able to fully solve Russian problems such as insufficient capital and technology to be improved; moreover, it will contribute to a more stable development of Russia's energy industry, greatly boost the development course of manufacturing industry and further promote the economic development in Siberia and the Far East regions.

\section{The Cooperation Should Be Helpful to Speed up the Cooperative Development in Sino-Russian Border Area}

The "Outline of Cooperation Planning between the Northeastern region of China and the Far East and Eastern Siberia regions of the Russian Federation (2009-2018)" formulated between China and Russia in September 2009 marked that the two sides fully affirmed the "revitalization of the Northeast of China" and the "development of the Far East of Russia". China and Russia both pay attention to the development in remote areas and hope to stabilize the bilateral partnership through strategic docking and further accelerate the pace of development. In September 2013, the National Development and Reform Commission of China issued the "Planning for Open Development along the Border of Heilongjiang and the Northeast region of Inner Mongolia". From this, it can be seen that China attached importance to Heilongjiang and the Northeast region of Inner Mongolia. Through this plan, it is feasible to create a good development environment for the two regions and effectively promote better and faster development of the two regions. In November 2013, the Third Plenary Session of the 18th CPC Central Committee included the "open development along the border" into the national strategy, which fully reflected China's concern for the development in border areas and further promoted the integration process between China and neighboring countries. In 2015, China and Russia launched the "Joint Statement of the People's Republic of China and the Russian Federation on the Docking Cooperation between the Construction of the Silk Road Economic Belt and the Construction of the Eurasian Economic Union"; this statement became an important mark of the major strategic docking between China and Russia and comprehensively accelerating the pace of cooperation.

\section{The Cooperation Should Be Helpful to Boost the Construction of Sino-Russian Express Freight Channel}

The convenient freight channel can help reducing the transaction cost of the main body, improving the transportation efficiency, and laying a good transportation foundation for the development of cross-border e-commerce. In recent years, Sino-EU bilateral trade maintains in continuous development and China opens up new railway freight routes; but there are problems of customs clearance in midway countries, so that the advantages of freight routes are not fully utilized, and the economic benefits are reduced in contrary. Although the infrastructure construction cooperation between the two sides is ongoing, the number of such projects implemented is small. For example, in March 2008, Sino-Russian Tongjiang-Nizhneleninskoye railway boundary river bridge project was officially approved. In October 2008, China and Russia signed a bridge construction agreement. Just for some reason, the project was not implemented. As the cooperation between China and Russia deepened, the two sides gradually focused on the cooperation in freight channel. In 2014, the Sino-Russian joint statement proposed to "accelerate the development of cross-border transportation infrastructures". In October 2014, the two countries explicitly proposed the co-construction of the Moscow-Kazan high-speed railway in order to boost the construction of a Eurasian high-speed traffic corridor from Beijing to Moscow. In 2015, President Putin clearly stated that it is expected to connect the Russia's Trans-Eurasian Railway with China's "Belt \& Road" to better promote the economic development of China and Russia. 


\section{CONCLUSION}

2019 is the 70th anniversary of the establishment of diplomatic relations between China and Russia and also the ending year of Sino-Russian local cooperation and exchanges; in this year, China and Russia enter a new stage of a comprehensive strategic cooperation partnership in the new era. In 2018, the trade volume between China and Russia exceeded 100 billion USD; the economic and trade cooperation between China and Russia reached a new historical level; and China has become Russia's largest trade partner for the sixth consecutive year. Against this background, Sino-Russian economic and trade cooperation is inevitably to actively strive for their respective interests and common interests to achieve a win-win situation.

\section{REFERENCES}

[1] Zhang Jinping. The Basis and Benefit of Strategic Docking of Regional Economic Cooperation between China and Russia [J]. Journal of Harbin Institute of Technology (Social Sciences Edition), 2016(1). (in Chinese)

[2] Xing Guangcheng. Sino-Russian Relationship: Successful Practice in Constructing New International Relations [J]. Contemporary World, 2015 (5). (in Chinese)

[3] Yu Jun. Status Quo and Perfecting Path of the Cooperation Mechanism between China and Central and Eastern European Countries[J]. International Studies, 2015(2). (in Chinese) 